\title{
THE PERSPECTIVE OF GLUSTER RANKING ANALYSIS IN THE DEVELOPMENT OF FOOD SAFETY MEASURES
}

\author{
Anca Băndoi ${ }^{1}$, Claudiu Bocean ${ }^{2}$, Aurelia Florea ${ }^{3}$, Dalia Simion ${ }^{4}$ \\ and Cătălina Sitnikov ${ }^{{ }^{*}}$ \\ 1) 2) 3) 4) 5) University of Craiova, Romania.
}

Please cite this article as:

Bădoi, A., Bocean, C., Florea, A., Simion, D. and Sitnikov, C., 2019. The Perspective of Cluster Ranking

Analysis in The Development of Food Safety

Measures. Amfiteatru Economic, 21(51), pp. 313-328.

\section{Article History}

Received: 17 December 2018

Revised: 15 February 2019

Accepted: 25 March 2019

DOI: $10.24818 / \mathrm{EA} / 2019 / 51 / 313$

\begin{abstract}
Food safety policies have gained considerable importance in recent years, food safety being one of the indicators that illustrates the standard of living and quality of life within a nation state. In order to assess food security, we analyzed the Global Food Security Index (GFSI) that, economically, is based on GDP, degree of poverty and agricultural production, extending also to areas such as government and public policies, which are usually not directly included in food safety indicators or generating factors.

Considering the importance and impact of food safety, starting from the theoretical concepts, from the current state of food safety in Europe, presented by the means of GFSI and its components, we developed a set of measures based on the grouping (correlation) of states following the analysis of hierarchical ranking of clusters. To analyse clusters hierarchical ranking the food safety indicators were used as input, dependent data. As an independent variable, with a strong influence on all the others, determined by means of multiple linear regression, we considered GDP/inhabitant at the level of each analysed state. The design of the set of measures considered the correlation that can be established among the various GFSI indicators that influence and generate the current state of food security in different European countries and the influence these indicators can have on maintaining or improving this state.
\end{abstract}

Keywords: Food Safety/Security, Global Food Safety Index (GFSI), hierarchical classification, clusters, GFSI dimensions.

JEL Classification: F52, H55, Q18, C43

* Corresponding author, Cătălina Sitnikov - inasitnikov@yahoo.com 


\section{Introduction}

Although, over the years and especially in the recent decades, food safety has improved significantly at global level, it can be seen that evolutions of different countries and regions have been uneven, with a significant percentage of the population displaying a low degree of safety in terms of food. In order to ensure global food security, the income should be increased, and awareness campaigns must be undertaken for these new higher incomes to translate into improved nutritional outcomes. Agriculture has a dual role in ensuring food safety by providing food with a rich nutritional content and by generating income to farmers. Policies aimed at improving productivity growth in agriculture, the sustainable development of agriculture and the improvement of social protection systems are more effective and have greater effects on food security than direct interventions that isolate markets by producers or consumers (OECD 2016). Even if global agricultural production has increased exponentially in the last century, there is a high percentage of the population who still has difficulty in accessing a diet with a high content of nutrients (Charles et al., 2010). That is why food safety has become a topical issue in recent years, hence, research activities and their significance will continue to keep on developing in the future (Chitea and Dona, 2018).

The OECD analysis (2015) shows that food security will benefit of the future production and market economy model based on the principles of sustainability. In a scenario where globalization focuses primarily on economic growth, food security can be affected due to rising prices, non-sustainability of production patterns and uncontrolled market behavior. The worst-case scenario for food security would be a manufacturing and business model based on internal and local self-reliance and on limited international cooperation. In the last decades, trade liberalization has led to the opening of markets, stimulating sustained global economic growth. The effect of these phenomena on food security cannot be clearly determined. A review carried out by McCorriston et al. (2013) of 34 studies focusing on determining the influence that liberalization of agricultural products trade performs or not on improving food security shows that there is no clear information (13 studies indicate improvement, 11 studies indicate decrease and 10 studies indicate mixed results). In another study, Olper et al. (2014) argue that there are heterogeneous effects of business relaxation on food security among 40 countries with low- and middle-income levels, but that, on average, these effects are positive.

In a European Union forecast, Mathijs (2015) complements the challenges of food security with the sustainable use of resources, climate change, social and economic conditions of agriculture, rural development policies, changes in food patterns, energy market dynamics, new relationships between industry and consumer, information revolution, non-food use of biomass. Keeping track of food security developments at the global level is essential for the development and evaluation of policies and programmes at the governmental and international level. However, identifying suitable indicators is a challenge. The construct of food security is multifaceted, proactive and adapted to the context. The underlying complexity of the concept, complicated by the challenge of data collection, has led to a true proliferation of indicators over the past two decades (Hoddinott, 1999; CFS, 2011; Thomas et al., 2017).

Admittedly, the Global Food Security Index (GFSI) is a complex index intended to check the trend of food security at country level. It was developed by the Economist Intelligence Unit (EIU) and funded and advocated by DuPont. It is calculated annually, starting from 
2012, and covers, as of 2014, 113 countries. Choosing a complex index has the advantage of summing up a large amount of information in a single figure that can be compared in time and space. It is a simplistic but effective approach to monitoring development in food security, as it significantly simplifies analyses and interpretations in making analogies among countries. Nevertheless, if the complex index is not properly constituted or is misinterpreted, it may be the basis of poor political conclusions and decisions lacking in substance, based on erroneous information.

Within this framework, the paper is structured in 5 sections. After an introduction presenting the main food security challenges, the second section outlines the conceptual framework of GFSI. In the third section, the methodological lines of the paper are drawn up, while the fourth section provides the findings and their interpretation, as well as the set of measures based on the grouping (correlation) of the states according to the analysis of the hierarchical ranking of the clusters proposed for the improvement of food security. The fifth section covers the conclusions, identifies research limitations and opens up directions of future research.

\section{Global Food Security Index (GFSI) Conceptual Framework}

Food security is identified as a state when "all people, at all times, have physical and economic access to a sufficient amount of safe and nutritious food that meet their food needs and dietary choices for a dynamic and healthful life" (FAO, 1996). This concept is employed by the Food and Agriculture Organization of the United Nations to identify food security as a four-sized concept (FAO, 2009). The four dimensions are: availability, access, use and stability.

In the same climate of opinion, the Global Food Security Index (GFSI) performs an assessment of the food security context, focusing on factors that determine food security, rather than on food security results. This index includes direct factors related to food security, such as food supply, the share of food in total individual spending, level of poverty or nutritional policies, but also extends and covers indirect factors such as availability of financial services, corruption, political steadiness, etc. Considering the wider area, and also taking into account factors indirectly affecting food security, the GFS index overlaps only partially with existing food security indicators on the ground that GFSI indicators are measured at the national level and not at the household level, assessing the average status in each country (EIU, 2018). GFSI presents good statistical characteristics using coherent and consistent quantification and aggregation methods. The indicators are on average significantly correlated with their size, and their analysis indicates that the three facets (accessibility, availability, and quality and safety) that make up GFSI record a constant behaviour (Thomas et al., 2017).

GFSI indicates the average (constructional or continual) rank of food security during a given period. In general, it does not describe the dramatic situation that characterizes recent changes to food security, being representative of a country's state of affairs merely to the point of the information (yet) describe the current situation. If the condition is secure and steady within a country, the GFSI score will illustrate correctly this condition. If, on the other hand, the condition is rapidly altering within a state, the GFSI score will illustrate the past situation and cannot be therefore used to monitor real-time food security. In the GFSI interpretation, it is important to bear in mind that the conditions that may lead to food 
security are measured, but the results regarding food consumption or the nutritional state of the population are not. The final score is intended to assess the status of food security or an opportunity for food security rather than the current level of food security.

The conceptual framework of GFSI is based on three dimensions of food security: accessibility, availability, and quality and safety. The three dimensions are illustrated by 19 synthetic indicators making up of 28 individual indicators. The 28 individual indicators are grouped in three areas: accessibility (6 indexes), availability (11 indexes) and quality and safety (11 indexes). The indicators included in GFSI, as well as their weight in the final score, were determined in consultation with a group of experts from the academic, nonprofit and public sectors (EIU, 2018). Starting with 2017, a fourth category (natural resources and resilience) was added to illustrate the impact of climate and natural resources. The overall GFSI score was still calculated using a simple weighted mean of the first three categories scores (accessibility, availability, quality and safety). This adjustment dimension "serves as a lens through which general food security can be seen" (EIU, 2018, p. 34) to explain some variations that cannot be accounted for by economic and social factors, but only by the average factor.

The GFSI's overall score was further calculated from a simple weighted average of the scores of the first three dimensions (accessibility, availability and quality and safety). The indicator scores are normalized (min-max) and take values from 0 to 100 , with 0 corresponding to the most unfavorable situation and 100 corresponding to the most favourable situation (EIU, 2018). Moreover, as mentioned before, the GFSI does not capture the entire spectrum of food security, reflecting the specific aspects chosen by the expert team that designed it. The index is based, economically, on the GDP, the degree of poverty, agricultural production, but also extending to areas such as government and public policies that are usually not directly included in the indicators or factors generating food security. It can therefore be used in a complementary way with other means of measuring food security, but it is not a substitute.

Thomas et al. (2017) shows that GFSI, just as any other complex index, does not enable the determination of a causal relationships among the indicator's dimensions (accessibility, availability, quality and safety), or among the individual indicators included in the three GFSI dimensions and food security. Any causal relation between any specific indicator and food security must be tested by a correlation or regression assessment among a specific indicator and a measurement expressing food safety results such as, for example, food consumption. Therefore, Thomas et al. (2017) recommends the use of the GFSI along with other indicators of food security, namely those measuring food safety outcomes for food consumption and nutritional status of the population in order to have a correct estimate of the contextual status of food safety.

\section{Research Methodology}

The potential of food security incidence on the development of each state reveals the importance of analyzing and researching the specific current factors generating this state and identifying those elements, which, through their influence, can change the future evolution of food security in a positive sense. Accordingly, using and adapting Saunders' deductive approach (Saunders et al., 2009), the research plan was drawn up by grouping (correlating) European states based on the value of the GFSI specific indicators' weights. 
The study coverage area comprised 26 European states (member and non-member states) which in 2018 were among those selected by the Economist Intelligence Unit in collaboration with Corteva Agriscience to participate in the annual study on the Global Food Security Index (EIU, 2018). The data used in the study were based on secondary sources, represented by all research and information made available by the Economist Intelligence Unit, World Bank, International Monetary Fund, the United Nations Organization for Food and Agriculture, Organization for Economic Co-operation and Development and the statistics of European Union and the states involved in research.

The multiple linear regression, grouping techniques, correlation analysis, and clusters ranking were used to describe the studied phenomena and to capture correlations between the variables and the influences among different dimensions of food security.

The research was conducted on three levels:

- the first level was constituted by the collection of data from the previously mentioned secondary sources and their processing using SPSS (IBM SPSS Statistics V.23). Data specific to each state and each indicator were used, identifying the statistically significant indicator. The identification was made using the multiple linear regression method.

- once identified, the indicator was used in the second level, which grouped, by the means of clusters ranking, the European states, depending on the similarities identified at the level of the indicators.

- the third level, represented by results and discussions, led to the creation of the set of specific and optimum measures to be applied in order to ensure food security in the light of each dimension and specific indicators.

For the identification of the most statistically significant indicator, at the level of all the indicators that influence and on which the GFSI is based, the multi-linear regression method was used, where the explanatory, independent variables are the indicators that make up the three dimensions of GFSI and which, in addition, substantiate and influence it (Annex 1 - Table no. 1). The dependent variable was represented by GFSI.

Thus, the established regression function was the form:

$$
\begin{aligned}
\text { GFSI }=\mathrm{P}_{1}+\mathrm{P}_{2} * & \mathrm{~V}_{1.1}+\mathrm{P}_{3} * \mathrm{~V}_{1.2 .}+\mathrm{P}_{4} * \mathrm{~V}_{1.3 .}+\mathrm{P}_{5} * \mathrm{~V}_{1.4 .}+\mathrm{P}_{6} * \mathrm{~V}_{1.5 .}+\mathrm{P}_{7} * \mathrm{~V}_{1.6 .}+\mathrm{P}_{8} * \mathrm{~V}_{2.1}+\mathrm{P}_{9} \\
& * \mathrm{~V}_{2.2 .}+\mathrm{P}_{10} * \mathrm{~V}_{2.3 .}+\mathrm{P}_{11} * \mathrm{~V}_{2.4 .}+\mathrm{P}_{12} * \mathrm{~V}_{2.5 .}+\mathrm{P}_{12} * \mathrm{~V}_{2.6 .}+\mathrm{P}_{13} * \mathrm{~V}_{2.7}+\mathrm{P}_{14} \\
& * \mathrm{~V}_{2.8 .}+\mathrm{P}_{15} * \mathrm{~V}_{3.1 .}+\mathrm{P}_{16} * \mathrm{~V}_{3.2 .}+\mathrm{P}_{17} * \mathrm{~V}_{3.3 .}+\mathrm{P}_{18} * \mathrm{~V}_{3.4 .}+\mathrm{P}_{19} \\
& * \mathrm{~V}_{3.5 .}
\end{aligned}
$$

$\mathrm{P} 1 \div \mathrm{P} 19$ are the regression parameters associated with each variable that compose the GFSI dimensions. P1 is the free parameter, which presents the potential value of the resulting variable if the influence of the factorial variables were 0 , and the parameters $\mathrm{P} 2 \div$ $\mathrm{P} 19$ indicate the influence that each variable to which the parameter is associated is at a $1 \%$ increase in the feature.

The statistical processing obtained the data in table 2, used for the construction of the specific regression function 
Table no. 2: Coefficients

\begin{tabular}{|c|c|c|c|c|c|}
\hline \multirow{2}{*}{ odel M } & \multicolumn{2}{|c|}{ Unstandardised Coefficients } & \multirow{2}{*}{$\frac{\text { Standardised Coefficients }}{\text { Beta }}$} & \multirow[t]{2}{*}{$\mathrm{t}$} & \multirow[t]{2}{*}{ Sig. } \\
\hline & $\mathrm{B}$ & Std. Error & & & \\
\hline (Const.) & 4,444 & 1,902 & & 2,336 &, 058 \\
\hline V1_1 & ,088 & ,001 & 075 & 74,951 & ,000 \\
\hline V1_2 &, 040 & 013 & ,003 & 3,198 & 019 \\
\hline V1_3 & 089 & ,001 &, 137 & 102,163 & 000 \\
\hline V1_4 &, 041 &, 001 &, 058 & 76,227 &, 000 \\
\hline V1_5 &, 054 & ,001 &, 060 & 37,641 & 000 \\
\hline V1_6 &, 046 & ,001 & ,068 & 49,900 & 000 \\
\hline V2_1 &, 088 &, 001 &, 136 & 94,030 & ,000 \\
\hline V2_2 & ,036 &, 000 &, 109 & 107,153 &, 000 \\
\hline V2_3 &, 054 &, 001 &, 120 & 63,063 & 000 \\
\hline V2_4 &, 060 &, 001 & 079 & 87,720 & , 000 \\
\hline V2_5 & ,044 & ,001 & , 100 & 83,669 & ,000 \\
\hline V2_6 & ,045 & ,001 &, 141 & 68,720 & ,000 \\
\hline V2_7 &, 044 & ,001 & ,037 & 36,614 & , 000 \\
\hline V2_8 & 059 & ,002 & 045 & 35,839 & ,000 \\
\hline V3_1 & ,034 & ,002 & ,041 & 21,110 & ,000 \\
\hline V3_2 & ,022 & ,000 & ,062 & 46,000 & ,000 \\
\hline V3_3 & ,042 & ,001 & ,044 & 36,217 & ,000 \\
\hline V3_4 & ,038 & ,001 & ,078 & 53,933 & ,000 \\
\hline V3_5 & ,019 & ,010 & ,003 & 1,856 &, 113 \\
\hline
\end{tabular}

As it can be seen, at the level of the indicators, the greatest influence has the variable V1_3 (GDP/inhabitant). Also, based on the values of the coefficients, the pattern of the multiple linear regression equation, resulting from the analysis carried out, has the following form:

$$
\begin{aligned}
\mathrm{GFSI}=4,444+ & 0,088 * \mathrm{~V}_{1.1}+0,040 * \mathrm{~V}_{1.2 .}+0,089 * \mathrm{~V}_{1.3 .}+0,041 * \mathrm{~V}_{1.4 .}+0,054 * \mathrm{~V}_{1.5 .}+0,046 \\
& * \mathrm{~V}_{1.6 .}+0,088 * \mathrm{~V}_{2.1}+0,036 * \mathrm{~V}_{2.2 .}+0,054 * \mathrm{~V}_{2.3 .3}+0,060 * \mathrm{~V}_{2.4 .}+0,044 \\
& * \mathrm{~V}_{2.5 .}+0,045 * \mathrm{~V}_{2.6 .}+0,044 * \mathrm{~V}_{2.7}+0,059 * \mathrm{~V}_{2.8 .}+0,034 * \mathrm{~V}_{3.1 .}+0,022 \\
& * \mathrm{~V}_{3.2 .}+0,042 * \mathrm{~V}_{3.3 .}+0,038 * \mathrm{~V}_{3.4 .}+0,019 \\
& * \mathrm{~V}_{3.5}
\end{aligned}
$$

Thus, it can be concluded that, in the case of study, the influence of GDP/inhabitant on the evolution of GFSI is an important one, for each increase by $1 \%$, it brings an increase in GFSI by $0089 \%$. By evaluating the validity of the model, it can be seen that it is correctly constructed, $\mathrm{R}^{2}$ and adjusted $\mathrm{R}^{2}$ values being almost 1.0 ( 0.97 and 0.98 respectively). Starting from this analysis, which identified and validated, with the help of multiple linear regression, GDP/inhabitant as the most statistically significant indicator, the creation of a set of specific and optimal measures to be implemented has been carried out in order to ensure food security from the perspective of each dimension and specific indicators.

To analyse the hierarchical classification of clusters, the specific indicators of the food security three dimensions (Accessibility, Availability, Quality and Safety) were considered as dependent inputs. The GDP per capita, identified before, was considered an independent variable, with a strong influence on all the others, at the level of each state covered by the analysis. The statistical method was selected to analyse the cluster hierarchical classification since it is the most common and generally applied, generating a series of 
models with solutions from 1 cluster (all cases considered positioned in one cluster) to $n$ clusters (each case considered to generate a cluster). Also, an additional consideration for choosing this method was that it uses variables in contrast to the cases considered, grouping them together in a way similar to factorial analysis. This analysis was used to organize the corresponding states into groups, considering their performance from the point of view of food safety specific indicator values. By grouping them into clusters, the states in the same cluster should be similar in terms of the analysed indicators, while clusters, as entities, should be as diverse as possible. Clusters represent sets of points located at small distances between them and spaced from points in other clusters. In determining clusters, in order to specify the proximity (similarity), we used the correlation coefficient that allows the evaluation of the intensity and meaning of the relationship between indicator values. Extreme values show a maximum or minimum intensity of the correlation. Maximizing the similarity, the degree of similarity of the analysed indicator values, thus minimizing the errors, was achieved by minimizing the sum of the squares of the residues.

$\min S=\min \sum e_{i}^{2}=\min \sum\left(y_{i}-\widehat{y}_{l}\right)^{2}$

where $e_{i}=$ residual value for element "i" from the analyzed indicator values

As a result of the classification algorithm and according to the data used, cluster grouping was obtained from the dendogram shown in figure 1 . By vertically cutting the dendogram, a partition of the set of classified elements is obtained, the components of the partition being the clusters determined.

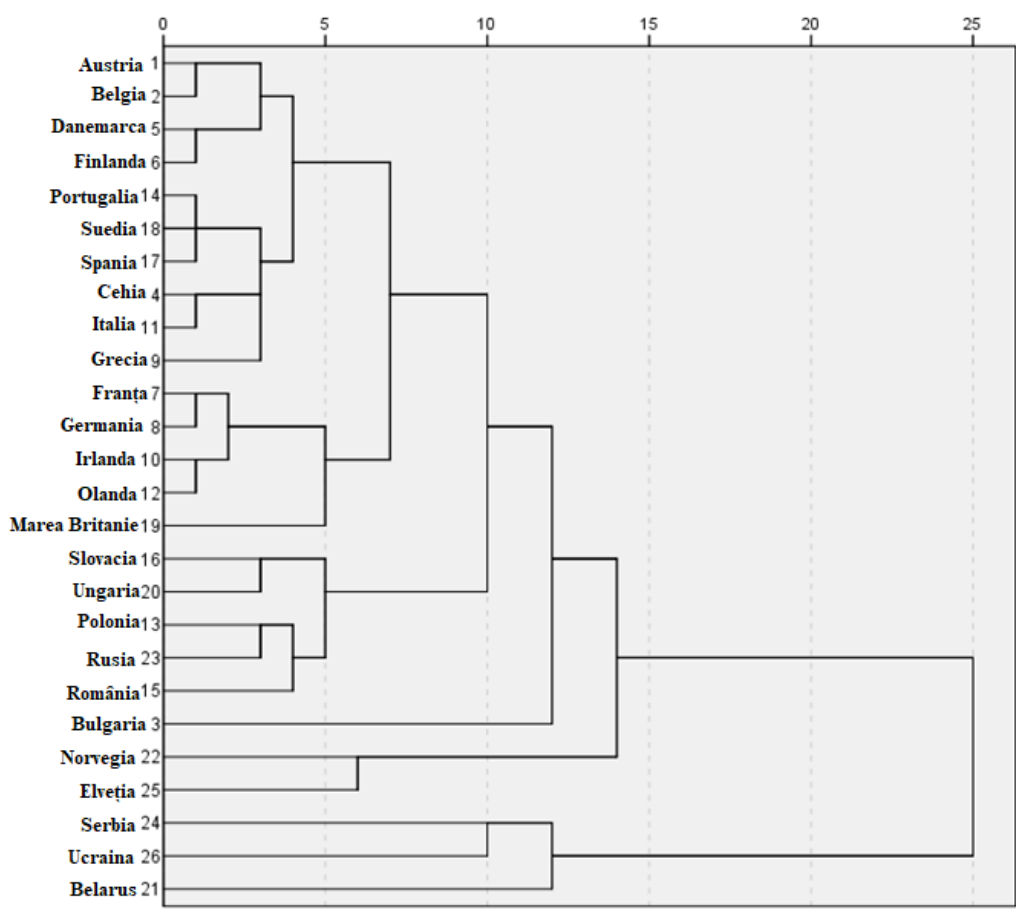

Figure no. 1: Grouping of European states on clusters

Source: authors own calculations based on data taken from the EIU 2018 and Corteva Agriscience DuPont 
The resulting grouping was of two clusters, the former including several sub-clusters. It is noteworthy that, in this cluster, there is also found the situation of Bulgaria, which presents itself as a separate cluster, individually, not included in the cluster with other states.

\section{Results and discussions by substantiating the generation of a set of measures by grouping (correlation) according to the hierarchical classification of clusters}

Assessing and analyzing clusters grouping in figure 1, it could be mentioned that the first cluster comprises six sub-clusters, each with a defined number of states, similar from different points of view.

The first sub-cluster includes four states: Austria, Belgium, Denmark and Finland. All of these countries fall into the category of developed countries with a high level of GDP, with values of 41.7, 39.4, 36.8 and 34.7, respectively, while the Degree of risk of political stability and Corruption is low, which eliminates any interference in use of funds needed for Investments in Agriculture, Agricultural Infrastructure, Public Expenditure on $\mathrm{R} \& \mathrm{D}$ Activities in the Agricultural Field. From the point of view of food security, the Percentage of the population below the global poverty lowest level is almost inexistent, and Dietary Diversification, Availability of Micro-nutrients, Protein Quality and Food Safety are far above average. Also, the Consumption of food relative to a household's income denotes a concern for saving, which is also observed at the level of Food Loss indicator, which is close to the minimum limit within the four states, with Finland found at the zero limit of losses.

The second sub-cluster includes six states: Portugal, Sweden, Spain, Czech Republic, Italy and Greece. All of these countries have implemented Food Safety Programs and provide Farmers Access to Finance, enjoying a low degree of Agricultural Production Volatility. Despite a high GDP in most of this sub-cluster states, there is a significant degree of Corruption, except for Sweden which has zero corruption. It is worth noting that all states, although with a special Agricultural Infrastructure, allocate important amounts for Agricultural R \& D. In conclusion, similarities exist at the level of all other indicators, irrespective of the fact that they are correlated with economic and social development or food consumption and security.

The third sub-cluster includes five states: France, Germany, Ireland, the Netherlands and UK. These countries are the most developed, with a high GDP per capita, a low rate of Corruption and Degree of political stability risk. Consumption of food as part of household expenditure is moderate, close to the minimum, which is also observed in correlation with the values of Food Loss and Dietary Diversification. In addition, all these countries allocate significant amounts to Agricultural R \& D, although they have, among other things, an Agricultural Infrastructure ranking above average, and even at the highest level in terms of the amounts invested. However, with respect to Food Quality and Safety indicators, represented by the Availability of Micro-nutrients and Protein Quality, it is worth noting the rather moderate levels in some of this sub-cluster states, a situation closely correlated with the high level of obesity.

The fourth sub-cluster includes five states: Slovakia, Hungary, Poland, Russia and Romania. These countries have recorded a fairly high share of Food Expenditures, especially Russia and Romania, a GDP below the European countries average, with values ranging from 24.6 in Slovakia to 19.4 in Russia, while Investments in Agricultural R \& D register some average to low values, there is a moderate level of Agricultural Infrastructure 
and the Volatility of Agricultural Production is at a fairly high level; however, the most important element to be noticed, with correlations and reverberations at the level of all others, is the medium to high degree of Corruption. From the point of view of Food Quality and Security, all of these states record low levels of Dietary Diversification, Availability of Micro-nutrients, Protein Quality, a fact that is translated into the high levels of obesity.

The fifth sub-cluster includes two states: Switzerland and Norway. These countries are the most developed, with a high GDP per capita (2nd and 3rd places at the level of analyzed states), a low rate of Corruption and Degree of political stability risk. Their grouping into a separate cluster, different from Cluster 3, is due to the fact that, outside the EU, they are featured by some characteristic elements, represented by the Tariffs of agricultural imports, which are unregulated and consequently different. Otherwise, the Consumption of food as part of the household expenditures is close to the minimum, which is also observed in correlation with the values of the Food Loss and Dietary Diversification indicators. It is worth noting that only Switzerland allocates significant amounts of money for Agricultural $\mathrm{R} \& \mathrm{D}$, in contrast with Norway, which does not allocate money to this indicator as a result of its geographic and climatic positioning. However, both countries enjoy an Agricultural Infrastructure close to the maximum level in terms of the amounts invested. In terms of Food Quality and Safety indicators, represented by Availability of Micro-nutrients and Protein Quality, the above-average levels of both states are noted.

The sixth sub-cluster includes only one state, Bulgaria, with a GDP level well below the average of European states, with a value of $15.4 \%$, a high degree of Corruption and Political Stability Risk. There is also a high share of Food Expenditures, while values of Investments in Agricultural R \& D and Agricultural Infrastructure are low. Volatility of agricultural production also stands at a high level. At the same time, from the perspective of Food Quality and Security, Bulgaria has average low levels of Dietary Diversification, Availability of Micro-nutrients, Protein Quality that can be observed in the high level of obesity.

The second cluster includes three states: Serbia, Ukraine and Belarus. Like Bulgaria, they have a GDP well below the average of the European states, with a value of $11.3 \%$ - Serbia, $6.2 \%$ - Ukraine and $14.3 \%$ - Belarus. There is obviously a high degree of Corruption and the high level of Political Stability Risk reflected in the low levels of Investments in Agricultural R \& D and Agricultural Infrastructure. The high share of Food Expenditures is also noted, while Food Loss is high in all three states. From the point of view of Food Quality and Security, Bulgaria has low average levels of Availability of Micro-nutrients and Protein Quality, which are reflected in the high level of obesity.

Starting from the interpretations of results obtained and the conclusions generated, it can be noticed that identifying the measures and the solutions needed to eliminate all the challenges raised by sustainable food security could be achieved and approached in different ways. Considering the evidence that food is based on two main pillars, economic capability (income, food prices, access to social benefits, etc.) and physical capability (infrastructure and investment in it), the generation of the set of measures must be carefully and thoroughly considered. There are some solutions for achieving global and sustainable food security, and these are neither highly industrialized farming nor organic farming on a small scale, but one new possibility, represented by the correlation and mix of the environment and technology, which results in sustainable development practices (Pinstrup - Andersen \& Watson II, 2011). The development of new technologies must be 
oriented towards implementing small-scale farming and small-scale agricultural products trading, practices from which small farmers benefit as long as national governments facilitate the policies and security measures needed in the transition to the integration into a global food security system (Schanbacher, 2010).

In the future, the food sector (including in this concept the whole chain: production, processing, distribution and use of food) should exploit the same resources as much as possible or even lesser as a result of the relative scarcity of resources, they should produce less waste from obtaining and using food, have a lower impact on the environment, provide the necessary nutrients and ensure accessibility and availability of food.

In a sustainable system of food security, it is necessary to start from the vectors influencing this system: economic, social, political, environmental, technological, and to establish strategies for the three large subsystems (production and sustainable supply, nutrition, health and wealth, adaptability) and for the three pillars (accessibility, availability, quality and safety). The correlations and logical links between all these elements are shown in figure 2 .

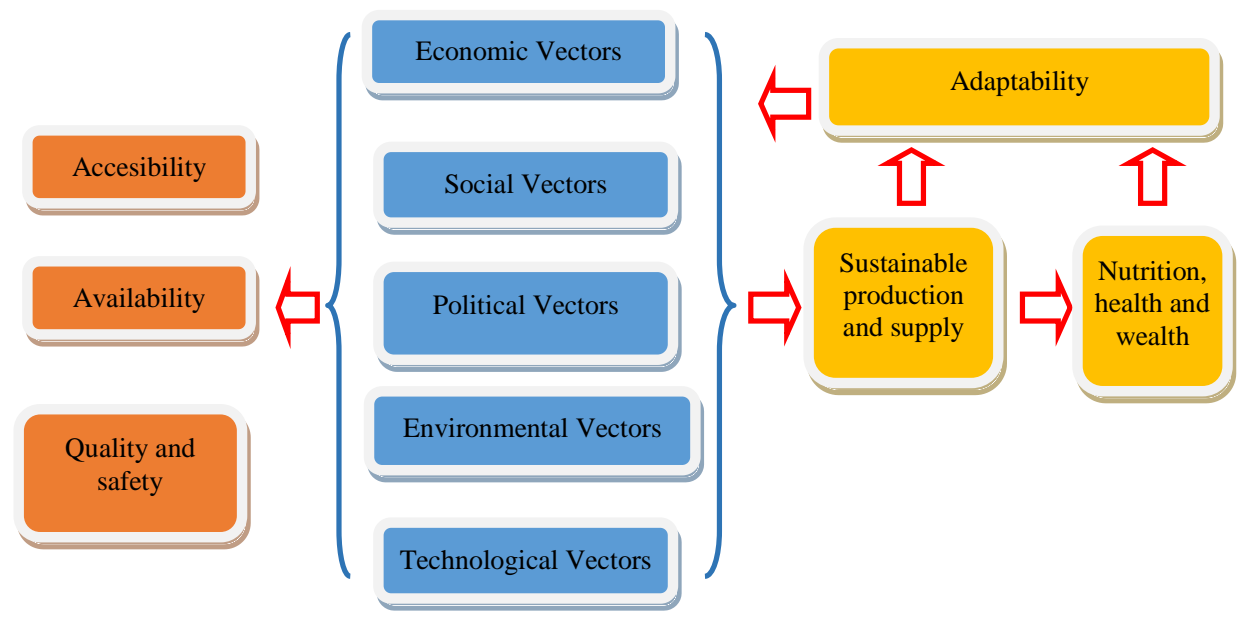

Figure no. 2: Ensuring the sustainability of Food System

Source: authors' own model based on information taken from GFS, 2017

Adaptability implies understanding and managing the risks in the food system caused by environmental, economic, social, political and technological shocks, their interaction and any ways to improve the resilience of the food system, both now and in the future. Sustainable production and supply refer to the sustainable provision of water, energy, nutrients and other necessary inputs, land and soils use, with particular emphasis on sustainable use of resources, improvement of efficiency and waste reduction, optimization of agricultural systems, increasing productivity of agricultural crops and animal husbandry, implementation of new technologies; in addition, the manufacturing, processing and distribution of food should be of optimal quality. Nutrition, health and wealth relate to food quality and safety throughout the supply chain, lifelong nutrition, healthy and sustainable nutrition, consumer behaviour, balanced food choices and access to food (GFS, 2017). Admittedly, a top-down approach is needed to create a set of measures that can help maintain or improve food security, grounded and geared towards 
raising the level of education and awareness, strengthening the social capital, and the GDP per capita growth.

\section{At the general level}

To further reduce food insecurity, Fan (2015) advocates a rethinking of the global food system, paying more attention to quality and safety of nutrition, diversification instead of specialization, food loss and waste reduction. Sustainable production consolidation should include a focus on nutrition. To achieve this, the following ways can be adopted: investment in agricultural research and development to produce more food with fewer resources, support for small-scale farming, promotion of policies and institutions capable to ensure better nutrition and security in food systems. Mathijs (2015) also advocates policies coherence and coordination to work towards a unitary approach to food systems.

Governments also have an important role to play in managing food price inflation and the value of currency, as all these macroeconomic forces can have rapid and devastating effects on food security. The provision of financial services, including low-cost, reliable and affordable credit and insurance options, can be a financial measure that can generate food security on the basis of financial security. Programs that correlate short-term assistance measures, such as conditional cash transfers, with long-term investment oriented towards improvement of soil or agricultural infrastructure can support the achievement of food security as complementary elements.

It is essential, from a political perspective, to resolve conflicts and ensure access to food during a conflict. Ideally, political and social systems need to improve adaptability through responsive support that meets the needs and requirements of domestic producers and consumers in terms of stable and predictable market dynamics, R\&D and infrastructure investment and facilitating trade and transport of agricultural products. Additionally, an innovation process is needed to eradicate corruption and programs aimed at eliminating losses in financial and food resources.

In recent years, it has been demonstrated that developing countries have benefitted from many open trade policies, resulting in high agricultural production and exports as well as very low agricultural price volatility. Regional trade agreements can also be a useful way of improving cross-border trade flows, especially if they are supported by efficient transport activities and logistics.

Investment in infrastructure that reduces losses and allows long-term storage of reserves is the basis of adaptability, providing farmers with more flexibility when marketing their products and the ability to respond to price signals (reflecting the abundance or deficit agricultural products).

\section{Application on dimensions}

- Improvement of the "Accessibility" dimension is important in many ways. However, there are several obstacles preventing this dimension improvement. One of these obstacles relates to the fact that income decreases with ageing, especially after retirement. The rate of non-accessibility of food is high among older adults, resulting in nutritional and negative health consequences, thus increasing the cost of medical services (Compte et al., 2017). The older the population, the greater the associated social costs. Accessibility is mainly linked to the share of spending on food consumption in total incomes, as well as to GDP per capita (Turan et al., 2018). The issue of rising food prices is another obstacle to improving this 
dimension. There are a number of reasons why global food prices may increase, which do not necessarily depend on markets and speculative movements in world food commodity prices: the consumption of animal food determines a substitution of land for crops dedicated to human consumption with land dedicated to feed livestock, subsidizing agricultural crops for the production of first-generation bio-fuels, increasing industrial production and related urbanization, which has determined the growth of agricultural crops' opportunity cost. Food prices growth will cause producers to market nutritionally poor foods.

Almost $30 \%$ of the food, accounting for about 1.3 billion tons of food produced in the world, is lost to the food system or turned into waste (FAO, 2011). Food losses mostly occur in the supply chain, while most food waste is produced by households. Given the context of relative resource scarcity, any loss of food needs to be analyzed and, as far as possible, avoided. Therefore, preventing food losses can lead to an improvement in food security, not only at national level but also at international level.

In addition, it can be observed that measures are needed to help vulnerable groups (short and medium-term measures as emergency food aid, increasing productivity and agricultural output) and establish the necessary framework to increase the income of those affected by hunger and chronic (long-term) food insecurity. At the same time, complementary investments in education should be made to improve nutritional outcomes (OECD, 2016).

Through the development of social protection systems and their specific elements of subsidies and aids (such as the minimum guaranteed income per capita), a better response to food security concerns than agricultural market interventions can be provided (OECD, 2016)

- With regard to improving the "Availability" dimension, the easiest solution, over time, has been to increase the amount of land used in agriculture and to exploit new fish stocks (Turan et al., 2018). However, the opportunity cost of these policies has increased significantly, as productive agricultural land has been recommitted due to urbanization and different ways of sustainable land management (Balmford et al., 2005). Investors are susceptible to investment in agriculture due to high input costs, fairly low returns and precarious and underdeveloped transport and market infrastructure. Although past improvements in agricultural production have greatly increased food yields and availability, the right nutritional balance has long been ignored. Nutrition studies provide valuable insights into the importance of nutrition in the development of individuals (Headey, 2015). Malnutrition suffered during early childhood has long-term effects on cognitive and learning outcomes, and subsequently on finding a job, adult wages, etc. While malnutrition is a problem that can be tackled through social assistance and financial programs, overfeeding can be irreversible because it can only be countered by behavioral changes generated by education. Individuals' health outcomes in healthier food systems are higher, and the action to create healthy eating habits can prevent higher costs in the future.

Investments in agricultural production systems will improve innovation and sustainable growth of productivity. Such measures include development of rural infrastructure, storage and processing facilities, training and counseling services for farmers (OECD, 2016). 
Ensuring more open and efficient agricultural markets at regional level will help increase demand and maintain stable prices, markets sending signals, through prices, to farmers in terms of the areas where it is most efficient to get certain products (Smith et al., 2017).

All this can be summed up in measures to improve access to financing for local farmers, investment in agricultural technology and R\&D activities.

- The dimension "Quality and Safety" illustrates the challenges that have arisen over the past decades: misuse and excessive use of agricultural chemicals, hazardous food residues, biologically contaminated food (Maxwell et al., 2014), poor quality products with security deficiencies found in developing countries (Levy et al., 2017). Therefore, developing specific food safety programs such as healthy food programs in schools, as well as promoting awareness of nutrition and its specific features, are measures that will prove their effectiveness.

\section{Conclusions}

Food safety is a complex and multidimensional issue related to the availability, accessibility and use of food over time. In general, food insecurity is caused by poverty, and requires actions to increase incomes for those affected by hunger and chronic food insecurity. Thus, based on the identification of GDP/capita as the most significant statistical indicator, with the help of the multi-linear regression method, the grouping of the European states was pursued, based on the hierarchical clusters ranking, according to the similarities identified at the level of the indicators composing the GFSI dimensions. As a result of clusters grouping, by their hierarchical classification, and of the set of measures generated by this grouping, we can note that, in addition to revenue growth, policies that translate revenue improvements into improved nutrition are needed. These policies are aimed in general at health, education, social protection, infrastructure, rural development, agriculture and economic policy.

Internal agricultural and commercial policies are critical components of the policy mix that affects food security, playing a dual role: increase income for poor producers and deliver food to consumers, signaling the necessity of market interventions. Market interventions create deficiencies in the production systems. On the one hand, they generate economic growth and revenue growth, critical for increasing food security. But at the same time, food prices are also rising, and households are consequently exposed to a reduction of purchasing power, both of which have disadvantages for the poorest and most unsafe households. Typically, these households spend more than half of their revenue on food.

The growth of population and income will exert additional pressure on food resources that are currently in a precarious balance. While food availability and accessibility remain an obstacle in some regions, the challenge of climate change is likely to exacerbate this problem. Limitations on access to food mainly relate to income disparities, while the challenge of using food is linked to both sub-production and over-production. To ensure food safety, a coherent and uniform approach to food systems is required. In terms of demand, challenges are raised by nutrition and health issues. As far as supply is concerned, the main challenge is agricultural production that must ensure food demand coverage in the light of climate change. Different agricultural production models based on different principles are being developed. Although many of the solutions could only be applied at 
regional level, global interaction requires coordinated approaches, among others in the area of trade policy.

Although research has been characterized by certain shortcomings (incomplete data, which influenced the ability of authors to use the fourth dimension of GFSI, represented by natural resources and adaptation capacity, as well as complementary variables), we can see that the proposed set of measures, both at the generic and each dimension levels, has materialized on the coherent processing of concrete data. As next steps of the research, we expect the set of measures to be generated, by collecting the missing data, which will be provided in the future by the EIU, on the basis of a new grouping based on the analysis of the hierarchy of clusters, starting from the assumption of the existence of a larger number of independent variables.

\section{References}

Balmford, A., Green, R.E. and Scharlemann, J.P.W., 2005. Sparing land for nature: exploring the potential impact of changes in agricultural yield on the area needed for crop production. Global Change Biology, 11(10), pp.1594-1605.

Braun von, J., Gerber, N., Mirzabaev, A. and Nkonya, E., 2013. The Economics of Land Degradation. ZEF Working Paper No. 109. [online] Available at: <https://ssrn.com/abstract=2237977> [Accessed 11 November 2018].

CFS, 2011. Measuring Food Insecurity: Meaningful Concepts and Indicators for EvidenceBased Policy Making. [pdf] Rome. Round Table on Monitoring Food Security. Available $<$ http://www.fao.org/fileadmin/templates/cfs_roundtable/Round_Table_technical_note. pdf $>$ [Accessed 11 November 2018].

Charles, H., Godfray, J., Beddington, J.R., Crute, I.R., Haddad, L., Lawrence, D., Muir, J. F., Pretty, J., Robinson, S., Thomas, S. M. and Toulmin, C., 2010. Food Security: The Challenge of Feeding 9 Billion People. Science, 327(5967), pp.812-818.

Chitea, L. and Dona, I., 2018. The Romanian Rural Household from Sustainable Rural Development Perspective. Scientific Papers Series „Management, Economic Engineering in Agriculture and rural development”, 18(1), pp.115-122.

Compte, V.M., Rossi, P.G. and Escamilla, R.P., 2017. Food insecurity measurement among older adults: Implications for policy and food security governance. Global Food Security, 14, pp.87-95.

European Commission, 2015. Global food security: challenges and options. [pdf] EU Agricultural Markets Briefs, No 9, November 2015. Available at: <https://ec.europa.eu/agriculture/sites/agriculture/files/09_en.pdf> [Accessed 18 November 2018].

Fan, S., 2015. Rethinking the global food system - Nutrition dimension. In: ICAE PreConference, Global Food Security Challenges. Milan, Italy, 7 August 2015.

FAO, 1996. World Food Summit. Food and Agriculture Organization of the United Nation, 13-17 November 1996, Rome, Italy.

FAO, 2009. Committee on world Food Security: Assessment of the world Food Security Situation. Rome: Food and Agriculture Organization of the United Nations. 
GFS, 2017. Global Food Security Strategic Plan. [pdf] London: Global Food Security. Available at: <https://www.foodsecurity.ac.uk/document/category/policies-strategies/> [Accessed 10 December 2018].

Headey, D.D., 2015. From food to nutrition security: The role of food policies. Washington DC: The International Food Policy Research Institute.

Hoddinott, J., 1999. Choosing Outcomes Indicators of Household Food Security. Technical Guide \#7. [pdf] IFPRI. Available at: <http://ebrary.ifpri.org/utils/getfile/collection/ p15738coll2/id/125736/filename/125767.pdf > [Accessed 10 December 2018].

Levy, T.S., Rosas, V.M., De la Vega, M.F. and Fernandez, C.L., 2017. Food Security Governance in Mexico. How can it be improved? Global Food Security, 14, pp.73-78.

Mathijs, E., 2015. Exploring sustainable futures through foresight. [pdf] University of Leuven. Available at: <https://ec.europa.eu/agriculture/sites/agriculture/files/expomilano-2015/cap-events/global-food-security-challenges/mathijs_en.pdf>[Accessed 10 December 2018].

Maxwell, D., Vaitla, B., Coates, J., 2014. How do indicators of household food insecurity measure up? An empirical comparison from Ethiopia. Food Policy, 47, pp.107-116.

McCorriston, S., Hemming, D.J., Lamontagne-Godwin, J.D., Parr, M.J., Osborn, J. and Roberts, P.D., 2013. What is the evidence of the impact of agricultural trade liberalisation on food security in developing countries? A systematic review. [pdf] EPPICentre, Social Science Research Unit, Institute of Education, University of London. Available at: <https://www.gov.uk/dfid-research-outputs/what-is-the-evidenceof-the-impact-of-agricultural-trade-liberalisation-on-food-security-in-developingcountries> [Accessed 10 December 2018].

OECD, 2015. OECD Long - Term Scenarios for Food and Agriculture. In: EAAE and IATRC Conference on Global Food Security Challenges. Milano, Italy, 7-8 August 2015.

OECD, 2016. Getting the Policy Mix Right for Global Food Security and Nutrition. [pdf] OECD Meeting of Agriculture Ministers, Background Note. Available at: <https://www.oecd.org/agriculture/ministerial/background/notes/8_background_note.pd f.> [Accessed 10 November 2018].

Olper, A., Curzi, D., Bedin, E. and Swinnen, J., 2014. Food Security, Health and Trade Liberalization. In: 3rd AIEAA Conference "Feeding the Planet and Greening Agriculture: Challenges and opportunities for the bio-economy". Alghero, Italy, 25-27 June, 2014.

Pinstrup-Andersen, P., and Watson, D.D. II., 2011. Food policy for developing countries: The role of government in global, national, and local food systems. Ithaca: Cornell University Press.

Saunders, M., Lewis, P. and Thornhill, A., 2009. Research Methods for Business Students. New York: Pearson.

Schanbacher, W.D., 2010. The politics of food: the global conflict between food security and food sovereignty. Santa Barbara: Praeger ABC-CLIO.

Smith, M.D., Kassa, W. and Winters, P., 2017. Assessing food insecurity in Latin America and the Caribbean using FAO's food insecurity experience scale. Food Policy, 71, pp.48-61. 
Thomas, A.-C., D'Hombres, B., Casubolo, C., Saisana, M. and Kayitakire, F., 2017. The use of the Global Food Security Index to inform the situation in food insecure countries. EUR 28885 EN, JRC, ISPRA.

The Economist Intelligence Unit (EIU), 2018. Global Food Security Index 2018. Measuring Food Security and The Impact of Resource Risks. [pdf] The Economist Intelligence Unit Limited. Available at: <https://foodsecurityindex.eiu.com> [Accessed 10 November 2018]

Turan, Ö., Gurluk, S. and Issi, E., 2018. Global Food Security Index's reflections to Balkan countries. Sciendo, 1(1), pp. 205-211.

Annex no. 1

Table no. 1: GFSI Values and the indicators included in GSFI for each European country

\begin{tabular}{|c|c|c|c|c|c|c|c|c|c|c|c|c|c|c|c|c|c|c|c|}
\hline & \begin{tabular}{|c|} 
V1.1. \\
Food \\
cons. as \\
share of \\
house \\
expend.
\end{tabular} & \begin{tabular}{c|} 
V1.2. \\
$\%$ of \\
pop. \\
under \\
global \\
pover. \\
line
\end{tabular} & \begin{tabular}{|l|} 
V1.3. \\
GDP/ \\
capita \\
\\
\\
\\
\end{tabular} & \begin{tabular}{|c|} 
V1.4. \\
Agricult \\
ural \\
import \\
tariffs \\
\end{tabular} & \begin{tabular}{|c|} 
V1.5 \\
Presence \\
of food \\
safety \\
net \\
program \\
mes
\end{tabular} & \begin{tabular}{|c|}
$\mathrm{V} 1.6$ \\
Access \\
to \\
financin \\
g for \\
farmers \\
\end{tabular} & \begin{tabular}{|c|} 
V2.1. \\
Suffici \\
ency of \\
supply \\
\end{tabular} & \begin{tabular}{|c|} 
V2.2 \\
Public \\
expendit \\
ure on \\
agricultulu \\
ral R\&D
\end{tabular} & \begin{tabular}{|c|} 
V2.3 \\
Agricultur \\
al \\
infrastruct \\
ure \\
\end{tabular} & \begin{tabular}{|c|}
$\mathrm{V} 2.4$ \\
Volatility \\
of \\
agricultu \\
ral \\
productio \\
n
\end{tabular} & \begin{tabular}{|c|} 
V2.5 \\
Politica \\
1 \\
stabilit \\
y risk \\
\end{tabular} & \begin{tabular}{|l|} 
V2.6 \\
Corup \\
\\
\end{tabular} & $\mid \begin{array}{c}\text { V2.7 } \\
\text { Urban } \\
\text { absorpti } \\
\text { on } \\
\text { capacity }\end{array}$ & \begin{tabular}{|l|} 
V2.8 \\
Food \\
loss \\
\\
\end{tabular} & \begin{tabular}{c|} 
V3.1 \\
Diet \\
diversifica \\
tion
\end{tabular} & \begin{tabular}{|c|} 
V3.2 \\
Nutrition \\
al \\
standard \\
s
\end{tabular} & \begin{tabular}{|c|}
$\mathrm{V} 3.3$ \\
Micronutrien \\
$\mathrm{t}$ availability
\end{tabular} & \begin{tabular}{|c|} 
V3.4 \\
Protein \\
quality
\end{tabular} & \begin{tabular}{|l|} 
V3.5 \\
Food \\
safety
\end{tabular} \\
\hline Austria & 93,3 & 99 & 41,7 & 81,9 & 100 & 100 & 100 & 25 & 100 & $\begin{array}{l}63,4 \\
\end{array}$ & 76,5 & 75 & $\begin{array}{l}78,8 \\
\end{array}$ & 93,8 & 93,1 & 100 & 56,5 & 72,6 & 100 \\
\hline Belarus & 48,1 & 100 & 14,3 & 81,7 & 100 & 100 & 81,8 & 0 & 41,7 & 89,2 & 29,4 & 50 & 71,2 & 95 & 75,9 & 0 & 58,1 & 85 & 98,6 \\
\hline Belgia & 86,7 & 99,8 & 36,8 & 81,9 & 100 & 100 & 98,8 & 25 & 89,8 & $\begin{array}{ll}61,8 \\
\end{array}$ & 70,6 & 75 & 77,8 & 95,4 & 89,7 & 100 & 58,9 & 73,8 & 100 \\
\hline Bulgaria & 76,4 & 97,6 & 15,4 & 81,9 & 75 & 100 & 67 & 25 & 61,1 & 62,1 & 64,7 & 25 & 91,1 & 65 & 67,2 & 100 & 31,1 & 47,1 & 99,5 \\
\hline Cehia & 80,4 & 100 & 28,3 & 81,9 & 100 & 100 & 82 & 25 & 80,6 & 87,1 & $\begin{array}{l}64,7 \\
\end{array}$ & 50 & 87,9 & 96,7 & 84,5 & 100 & 51,1 & 54,7 & 99,9 \\
\hline $\begin{array}{c}\text { Danemar } \\
\text { ca }\end{array}$ & 90,5 & 99,7 & 39,4 & 81,9 & 100 & 100 & 85,9 & 0 & 89,8 & 97,8 & 76,5 & 75 & 77,9 & 92,4 & 89,7 & 100 & 56,7 & 80,4 & 100 \\
\hline Elvetia & 95,1 & 100 & 50,2 & 44,1 & 100 & 100 & 86,8 & 50 & 100 & 84,2 & 82,4 & 100 & 74,3 & 97,4 & 100 & 100 & 54,2 & 63,7 & 100 \\
\hline Finlanda & 89,2 & 100 & 34,7 & 81,9 & 100 & 100 & 86 & 12,5 & 100 & 86,6 & 82,4 & 100 & 81,2 & 100 & 84,5 & 100 & 57,3 & 100 & 100 \\
\hline \begin{tabular}{|l|} 
Franta \\
\end{tabular} & 86,6 & 99,8 & 34,2 & 81,9 & 100 & 100 & 90 & 50 & 100 & 93,6 & 64,7 & 75 & 77,1 & 94,6 & 86,2 & 100 & 72 & 84,9 & 100 \\
\hline $\begin{array}{c}\text { Germani } \\
\text { a }\end{array}$ & 92,1 & 100 & 39,3 & 81,9 & 100 & 100 & 90,6 & 50 & 89,8 & 87,7 & 82,4 & 75 & 78,2 & 93,9 & 89,7 & 100 & 50,9 & 76,2 & 100 \\
\hline Grecia & 80,4 & 97,8 & 20,4 & 81,9 & 75 & 75 & 87,1 & 0 & 70,4 & 91,4 & 64,7 & 25 & 77,5 & 87,1 & 84,5 & 100 & 69,6 & 77,1 & 100 \\
\hline Irlanda & 94 & 99,3 & 60 & 81,9 & 100 & 100 & 94,1 & 62,5 & 80,6 & 75,7 & 76,5 & 75 & 92,4 & 94,3 & 79,3 & 100 & 69 & 87,6 & 99,2 \\
\hline Italia & 85 & 98,1 & 31,4 & 81,9 & 100 & 100 & 93,4 & 12,5 & 71,3 & 91,5 & 52,9 & 25 & 76,6 & 95,5 & 81 & 100 & 67,2 & 75,1 & 100 \\
\hline Norvegia & 88,3 & 99,8 & 47,7 & 34,6 & 100 & 100 & 90,1 & 0 & 89,8 & 92,4 & 100 & 100 & 73,9 & 96,9 & 86,2 & 100 & 60 & 89,2 & 100 \\
\hline Olanda & 89,8 & 99,8 & 41,4 & 81,9 & 100 & 100 & 81 & 75 & 89,8 & 89,5 & 76,5 & 100 & 80,1 & 97 & 91,4 & 100 & 56,7 & 91 & 100 \\
\hline Polonia & 79,9 & 100 & 22,3 & 81,9 & 100 & 100 & 88,9 & 37,5 & 70,4 & 90,5 & 47,1 & 50 & 91 & 90,6 & 69 & 100 & 51,6 & 70,4 & 98,5 \\
\hline $\begin{array}{c}\text { Portugali } \\
\mathrm{a}\end{array}$ & 79,7 & 99,1 & 24,7 & 81,9 & 100 & 100 & 89,8 & 12,5 & 90,7 & 92 & 82,4 & 50 & 80,7 & 92,7 & 82,8 & 100 & 70,7 & 92,6 & 99,9 \\
\hline Romania & 43,2 & 99,1 & 19,6 & 81,9 & 100 & 100 & 85,6 & 25 & 51,9 & 69,2 & 64,7 & 25 & 100 & 95,3 & 60,3 & 100 & 55,9 & 65,7 & 100 \\
\hline \begin{tabular}{|l|} 
Rusia \\
\end{tabular} & 55,7 & 100 & 19,4 & 82,1 & 100 & 100 & 85,7 & 12,5 & 50,9 & 76,9 & 35,3 & 0 & 75,8 & 95,5 & 69 & 100 & 55,2 & 72 & 97,5 \\
\hline Serbia & 62,4 & 99,7 & 11,3 & 77,3 & 75 & 75 & 50,1 & 12,5 & 61,1 & 74,2 & 47,1 & 25 & 86 & 89,4 & 67,2 & 34,6 & 47,6 & 48 & 93,8 \\
\hline Slovacia & 78,1 & 99,1 & 24,6 & 81,9 & 100 & 75 & 71,1 & 25 & 61,1 & 80,4 & 64,7 & 50 & 89,6 & 94,7 & 74,1 & 100 & 46,8 & 31 & 98,5 \\
\hline \begin{tabular}{|l|} 
Spania \\
\end{tabular} & 86,5 & 988,4 & 29,4 & 81,9 & 100 & 100 & 79,1 & 25 & 90,7 & 87,4 & 58,8 & 50 & 85,7 & 93,6 & 89,7 & 100 & 63,6 & 78,8 & 100 \\
\hline Suedia & 88,3 & 99,3 & 39,5 & 81,9 & 100 & 100 & 79,3 & 0 & 100 & 92,5 & 82,4 & 100 & 79,3 & 96,1 & 91,4 & 100 & 53 & 89,7 & 100 \\
\hline Ucraina & 34,9 & 99,8 & 6,2 & 85,1 & 75 & 50 & 64,5 & 12,5 & 41,7 & 84,6 & 11,8 & 0 & 85,1 & 90,4 & 67,2 & 65,4 & 52 & 53,8 & 98,4 \\
\hline UK & 96,7 & 99,8 & 33,4 & 81,9 & 100 & 100 & 87,9 & 100 & 89,8 & 93,1 & $\begin{array}{l}64,7 \\
\end{array}$ & 100 & 75,8 & 97,5 & 84,5 & 100 & 56,1 & 77,9 & 100 \\
\hline Ungaria & 77,3 & 99,1 & 21,9 & 81,9 & 100 & 100 & 74,3 & 37,5 & 71,3 & 65,1 & 70,6 & 50 & 86,4 & 93,5 & 86,2 & 100 & 49,9 & 47,7 & 100 \\
\hline
\end{tabular}

